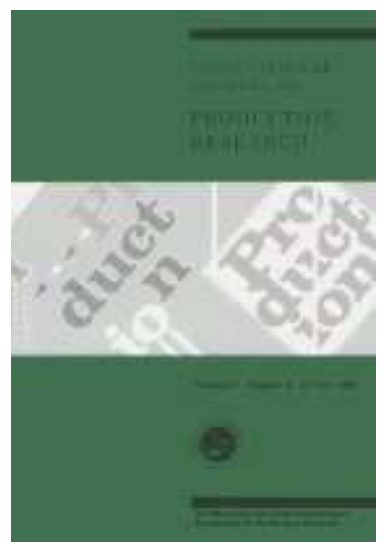

\title{
A technology selection framework for integrating manufacturing within a supply chain
}

\begin{tabular}{|r|l|}
\hline Journal: & International Journal of Production Research \\
\hline Manuscript ID: & TPRS-2010-IJPR-1020.R1 \\
\hline Manuscript Type: & Original Manuscript \\
\hline $\begin{array}{r}\text { Date Submitted by the } \\
\text { Author: }\end{array}$ & 22-Feb-2011 \\
\hline Kemplete List of Authors: & $\begin{array}{l}\text { Farooq, Sami; Aalborg University, Center for Industrial Production } \\
\text { O'Brien, Chris; The University of Nottingham Ningbo Campus, } \\
\text { Division of International Business }\end{array}$ \\
\hline Keywords (user): & MANUFACTURING MANAGEMENT, TECHNOLOGY MANAGEMENT \\
\hline & Technology Selection, Supply Chain \\
\hline
\end{tabular}

\section{SCHOLARONE Manuscripts}


4

5

10

11

12

13

14

15

16

17

18

19

20

21

\title{
A technology selection framework for integrating manufacturing within a supply chain
}

\author{
Sami Farooq* and Chris O'Brien ${ }^{1}$ \\ Center for Industrial Production* \\ Aalborg University \\ Fibigerstrcede 16, 9220 Aalborg, Denmark \\ Division of International Business ${ }^{l}$ \\ The University of Nottingham Ningbo Campus \\ 199 Taikang East Road, University Park, Ningbo 315100, China
}

Corresponding Author: Sami Farooq ${ }^{*}$

Email: sami@production.aau.dk

Tel: +4599407119

Fax: +45 98153040 htp://mc.manuscriptcentral.com/tprs Email: ijpr@lboro.ac.uk 


\title{
A technology selection framework for integrating manufacturing within a supply chain
}

\begin{abstract}
This paper describes a structured analytical approach for selecting a manufacturing technology. A framework consisting of six integrated steps is proposed by considering the growing importance of supply chains in manufacturing organisations. The framework makes use of Analytical Hierarchy (AHP) approach combined with Strategic Assessment Model (SAM) to evaluate and select the technologies appropriate for providing overall competitive advantage. The framework is intended to assist industrial managers in promoting manufacturing and supply chain collaboration and coordination by including intra-organisational perspective in their organisational technology selection decision making process.

Keywords: Manufacturing; Technology Selection; Supply Chain
\end{abstract}

\section{Introduction}

Realising the change in the global business environment companies in the manufacturing industry are collaborating with the suppliers and customers in their unique supply chains to achieve the seamless integration of manufacturing and supply chain. A greater level of communications among manufacturing decision makers and external sources of information, and knowledge related to capabilities, technologies and strategies affecting the manufacturing plant, leads to better manufacturing competitiveness and improvement programmes (Rosenzweig et al., 2003), and enables the manufacturing plant organisation to anticipate and more fully respond to 
changes in a customer's specific needs, new markets and technological opportunities. Therefore, strategic manufacturing integration with the supply chain involves knowledge dissemination and sharing activities that create new knowledge, which in turn improves organisational capabilities (Swink et al., 2007).

The manufacturing companies are looking to improve their bottom lines with more effective supply chain collaboration and coordination. Therefore, by considering the advantages of collaboration in the supply chain for improving manufacturing capability of a company and the dependence of a supply chain on a co-ordination mechanism for achieving a greater level of integration, this paper presents a technology selection framework for manufacturing technology integrating manufacturing and the supply chain in a single decision making loop. The developed technology selection framework improves the manufacturing capability of a company by helping it select the desired manufacturing technology. At the same time the framework acts as a co-ordinating mechanism between manufacturing and the supply chain providing the initial guidelines towards supply chain integration by considering inter-organisational factors in a company's technology selection decision making process.

\section{Research aim and context}

The aim of this study is to provide manufacturing managers with a decision making framework to decide analytically from among various manufacturing alternatives, 
when making key decisions regarding technology selection, so that their decisions are consistent with the overall objective of the supply chain (business). This research consisted of two stages that included development of a technology selection framework and the detailed operationalisation of the technology selection framework in industry. The development of the technology selection framework was carried out by reviewing the literature, engaging with a 'University Technology Centre' and involving company managers. The technology selection framework developed was then implemented in an industrial case study to determine its functionality. The initial framework was also presented to academics in the shape of an academic paper. The feedback from the academics and the observations from the industrial case study helped in the detailed implementation of technology selection framework in an aerospace manufacturer (Farooq and O'Brien, 2010). The purpose of this paper is to elaborate different steps that constitute the technology selection framework and the use of various analytical tools and their incorporation in the presented framework.

\section{Literature relevant to the technology selection process}

The role of technology as a major decision area within manufacturing strategy has been recognised for some time (Hayes and Wheelwright, 1984; Fine and Hax, 1985). The researchers have employed various criteria's like culture (Chatterji, 1996), long term competitive goals (Gagnon and Haldar, 1997) and technology life cycle (Gregory et al., 1996; Kim, 2003) for technology evaluation and selection purpose. A 
number of technology selection approaches from literature are described in this section.

In order to understand the holistic impact of the technology selection process the concept of value chain and firm as a unit of analysis was first used by Kleindorfer and Partovi (1990). The filter scanning approach for the selection of technology had been proposed and implemented by various researchers (Yap and Souder, 1993; Shehabuddeen et al., 2006). In the case of filter scanning approach the technology alternatives need to pass through all the barriers in order to be selected as the most desired technology. The use of 'Data Envelopment Analysis' (DEA) for technology selection process is preferred by many researchers over the years (Khouja, 1995; Karsak and Ahiska, 2005; Amin et al., 2006, Karsak and Ahiska, 2008). Similarly, 'Quality Function Deployment' (QFD) has also been used as a tool in the technology selection process (Lowe et al., 2000). The need to establish a link between strategic objectives of a company and the competitive advantage offered by a technology are strongly advocated and researched (Mohanty and Deshmukh, 1998; Kengpol and O'Brien, 2001; Torkkeli and Tuominen, 2002, Punniyamoorthy and Ragavan, 2003). The concept of resource based view (RBV) has also been employed for technology selection process (Gouvea da Costa et al., 2006). The resource based view illustrates that a firm's competitive positioning depends upon its unique resources and capabilities. 


\subsection{Shortcomings of the existing frameworks, processes and tools}

The risk associated with a technology can be positive in terms of opportunity or it can be negative in the shape of a threat perceived with a technology alternative. The technology selection processes in the literature have mostly considered opportunities related with a technology and have not included the threats associated with a technology alternative while considering it for strategic selection. The literature does not provide any study that incorporates the importance of the supply chain in the technology selection decision making process especially from the perspective of manufacturing organisations which are dependent on advanced manufacturing technologies for their competitive advantage and are having extended supply chains.

The traditional perspective of strategy formulation is that every firm is concerned with formulating its own organisational strategies independent of the strategies formulated by other members of the network. This approach supports the view that competitive advantage is sought on an organisation specific basis rather than on the basis of the value chain to which the firm belongs. However, recent research examining networks suggests that networks can be a source of competitive advantage (Dyer, 1996; Dyer and Singh, 1998; Poirier, 1999). This has shifted the focus of competitive advantage from the single organisation to inter-organisational resources. As the attention is shifted from a single organisation to the entire network so the term ‘supply chain' evolved. In modern business environment companies compete with each other for position in a desirable supply chain and work towards becoming a valued member of the supply chain (Fine, 1999). The individual capabilities of 
different supply chain members provide a pool of resources for the constituent supply chain in their competition against the other supply networks. Therefore, in the network context the success of a company and supply chain is linked tightly with each other and the competitive success of a supply chain is needed to guarantee the success of individual (company) supply chain member.

Mostly, technology selection models have been developed to assess the financial benefits of the candidate technology. This is the main reason they have been subjected to criticism over the period of time (Kleindorfer and Partovi, 1990; Shehabuddeen et al., 2006). Considering the available literature on technology selection process following shortcomings can be highlighted:

1. The technology selection processes fail to incorporate risk calculations in strategic technology selection.

2. The threats associated with a technology alternative have not been considered in the technology selection process and their importance in technology evaluation is neglected.

3. The existing technology selection processes do not provide support for the inclusion of inter-organisational factors in the technology selection decision making environment.

The field of supply chain has evolved rapidly in the last few decades. As more and more companies are going global, so they are forced to think beyond the four walls of their company. This research introduces the concept of integrating manufacturing and 
supply chain in a single decision making loop while making strategic decisions regarding the selection of a manufacturing technology. A technology selection decision making framework is developed in this research and it aims to answer the gaps identified in the existing literature.

\section{Proposed technology selection framework}

A framework for technology selection is proposed considering the role and significance of advanced technology as enablers of manufacturing and supply chain strategy. The proposed framework is inspired from already available technology selection frameworks in the literature and aims to develop a simple and efficient decision making framework which is easy to understand, covers all areas regarding technology selection and can be readily applicable in any type of industry. This framework combines supply chain and manufacturing together to achieve the business objective. This framework takes into account not only the views of the experts and managers of the company (see Appendix A) but also gives due consideration to the capabilities and requirements of the other supply partners. This helps in understanding the dynamics of the supply chain which simplifies the process of making the correct decision for technology selection that is best not only for the company but is also in the interest of the supply chain. A technology selection framework that incorporates manufacturing and supply chain objectives in a single decision making framework is presented. The framework for manufacturing technology selection consists of six steps as shown in the figure 1: 
Insert Fig. 1. Proposed technology selection framework

\subsection{Evaluation of current supply chain}

Step 1 of this framework is to evaluate the current supply chain performance of a product for which there are more than one technology alternatives available. The main attribute of step 1 is the involvement of the relevant company managers in evaluating the importance of various supply chain parameters from their own organisational perspective and then determining the performance of their suppliers in fulfilling the supply chain parameters. Similarly, the importance of defined supply chain objectives is carried out from market perspective and then the current performance of the company in the market is determined against likely competitors. This provides firsthand picture to a company about their performance as compared to the market needs and demands and directs them towards their strong and weak links in order to sustain the increasing pressure from their competitors. This leads to the reevaluation of their business strategy and provides them with an indication of into which areas they need to put in more effort and the areas where they are doing better than their competitors. By reviewing the literature and discussing with the company managers five performance measures in the shape of cost, quality, lead time, flexibility and new product development (NPD) are selected for the evaluation of current supply chain. Use of the importance performance matrix developed by Slack (1994) is proposed for the evaluation process. The importance-performance matrix is supposed to help in setting the priorities. The importance- performance matrix is used 
in this process to observe the performance of the supply chain compared to its competitors with reference to a particular performance metric. The results obtained are plotted on the importance performance scale depicting the true picture of the supply chain.

\subsection{Critical supply chain factors for competition}

Step 2 is the clear identification of the critical factors on which a supply chain plans to compete. Once the strength and weaknesses of the supply chain are indicated the next step is to select a few factors from the indicated factors for re-defining the business strategy according to the market condition. The major outputs from this step are the identification of the core competencies and defined set of factors for market competition.

\subsection{Time horizon}

Step 3 is to define the planning range for the supply chain to compete on the factors defined in the second step. The supply chain members may wish to compete on a long, medium or short term basis. The major input is the re-defined business strategy that is the product of the second step described above. Another input is the nature of the market and business in which the supply chain is planning to compete. The major output of this step will be the future vision of the business and the supply chain. 


\subsection{Identification of manufacturing technologies}

Step 4 in the framework is to identify the suitable manufacturing technologies to fulfil the critical supply chain objectives defined in the second step. This involves the input of a technology scanning process and requires carefully selected experts who understand the technical conformance expected from the selected technology.

\subsection{Detailed assessment of identified technologies}

Step 5 is the detailed assessment of the identified technologies. A review of the literature shows the availability of various techniques for multi-criteria decision making such as ranking of alternatives, scoring models, utility models, fuzzy techniques, analytical hierarchy process and multi objective mathematical programming techniques such as goal programming. This framework makes use of the analytical hierarchy process (AHP) developed by Saaty (1980) and the strategic assessment model (SAM) presented by Tavana and Banerjee (1995). In this step there is an effort to bridge the gap between the business objectives and the manufacturing capabilities of the supply chain. This has been done by dividing the decision making environment into manufacturing, supply chain and general environment and by determining the probability of occurrence of the opportunities and threats associated with each technology alternative in three different decision making environments. 
The purpose of the division into manufacturing environment is to analyse the available technology alternatives in the perspective of manufacturing opportunities and threats associated with a particular technology. Similarly, supply chain environment includes opportunities and threats associated with a technology alternative in the supply chain context. This enables the selected experts to visualise the technology assessment from a wider supply chain perspective. Finally, a general environment is defined which looks after mainly the economic opportunities and threats associated with technology alternatives. The inclusion of general environment opportunities and threats is aimed to include wider justification of selected technology alternative. The output of the process is the identification of possible technologies to achieve manufacturing and supply chain goals and the detailed characteristics of each available technology alternative.

\subsection{Risk assessment of technology alternatives}

The final step is the risk assessment of the identified technologies in which the risk associated with each technology alternative in terms of opportunity and threat is evaluated before selection. The output of this step is the overall risk adjusted technology strategic value which is the algebraic sum of risk adjusted technology opportunity value and risk adjusted technology threat value.

The technology selection processes, methodologies and techniques presented in the literature have been found short of any sort of risk assessment of the available 
technology alternatives for the technology selection process. The literature has been advocating the role of risk associated with technology alternatives but presented no means of risk evaluation. Keeping in view the importance of risk evaluation in the technology selection process, the technology selection framework developed incorporates the 'Strategic Assessment Model' presented by Tavana and Banerjee (1995) in the existing framework. The SAM provides the facility to calculate the risk associated with each technology alternative in terms of opportunities and threats. Therefore, the risk calculations provide a greater level of analytical comprehensiveness to the technology selection process. A number of different analytical techniques and concepts are used in SAM to supplement managerial intuition, knowledge and judgement. One of the major applications of SAM has been in NASA for evaluating and prioritising advanced technology projects (Tavana, 2003).

\section{Industrial Application}

In order to observe the functionalities of the technology selection framework and to determine the industrial applicability of the technology selection process it was decided to implement the technology selection framework in an industrial setup where technology selection decision making was an area of concern for the technology selection managers.

\subsection{Case study "A Bag in Box"}


One of Europe's largest producers of recycled paper and corrugated packaging presents "Bag in Box" as a packaging solution that combines the advantages of cardboard with a plastic bag interior. The products lightweight design offers high stacking strength and is suitable for various applications such as cooking oils or any other liquid. As a part of the product offer, the company wanted to supply its customers not only with packaging material but also with case erecting and bag insertion machinery. Therefore, a machine was required for obtaining consistently high quality and accuracy in placing and securing the folded bag into the erected box and then expanding the inserted bag for filling. The packaging company contacted an industrial outfit that provided innovative automation machinery and automated production systems for the automotive, food and drink, consumer goods and general manufacturing industries. The technology selection framework presented in this paper was used to determine the best technology alternative for placing the folded bag into the erected box.

The importance and performance of various supply chain objectives for "Bag in Box" assembly were determined by engaging the supply chain managers of the company using the questionnaire provided in appendix B and are plotted on the importanceperformance graph as shown in figure 2 .

Insert Fig. 2. Bag in Box importance performance for supply chain objectives It is clear from the above graph that cost and new product development (NPD) are prioritised as very important by the company and the performance of the supplier in 
satisfying these performance objective is good for cost placing it in the improvement zone on the above graph and satisfactory for NPD which makes it fall in the region of urgent action on the above graph. This means cost needs to be improved to stay competitive and the performance of the supplier in achieving NPD needs urgent action if the company plans to prioritise NPD as a highly important supply chain performance objective. Similarly, lead time, flexibility and quality falls into the urgent action zone in the graph and needs to be looked at immediately.

The market evaluation of "Bag in Box" was the next step and again supply chain managers were employed to perform this task using the questionnaire provided in appendix B. Figure 3 shows the market evaluation of "Bag in Box" assembly. Looking at figure 3 it can be easily seen that cost falls in the urgent action zone meaning that it is highly desirable in the market but the performance of the company in achieving it is below the industry standard or less than to compete with other competitors. Whereas lead time, quality, flexibility and new product development (NPD) are placed in the appropriate zone meaning the performance of the company in achieving these objectives is considerably better than the nearest competitor.

Insert Fig. 3. Bag in Box market evaluation

Three different manufacturing technologies were identified for "Bag in Box" assembly classified as:

- Robot Based Technology (Highly Flexible/Automated)

- Server Driven Flexible Technology (Moderately Flexible) 
- Existing Technology (Low Flexibility)

The opportunities and threats associated with each technology alternative identified were brainstormed with the technology managers and classified into manufacturing, supply chain and general decision making environments as shown in figure 4 and figure 5 .

Insert Fig. 4. AHP Bag in Box hierarchy (Opportunities)

Insert Fig. 5. AHP Bag in Box Hierarchy (Threats)

The probability of occurrence of each opportunity and threat associated with available technology alternatives in three decision making environments was determined by using a questionnaire (appendix C) with technology managers. The questionnaire helped in determining the percentage probability of achieving a desired opportunity or a perceived threat by using subjective judgement of technology managers. The percentage probability is converted to numbers $(0.1$ to 0.9$)$ in the step3 of appendix D where (0.1) shows 10 percent probability and (0.9) shows 90 percent probability. For example, the probability of occurrence of reduction of staff considering robot based technology in manufacturing environment was suggested $30 \%(0.3)$ as shown in step3 of the opportunity calculations in appendix D by the technology managers. Similarly, robot based technology offered probability of increased productivity as $90 \%(0.9)$. In the supply chain environment server driven flexible technology offered probability of $70 \%(0.7)$ considering long term strategic relationship with suppliers. This means the selection of server driven flexible technology will benefit not only the manufacturing 
requirement of the company but will also help to strengthen the relationship with strategic suppliers of the company. Now considering the probability of threats associated with technologies we can observe that technology managers recommended that the biggest possible threats with robot based technology (50\%) and server driven flexible technology $(40 \%)$ were training expenses as shown in the step3 of the threat calculations in appendix D.

The pairwise comparison was determined between different opportunities and threats in three different decision making environments using AHP. In step6 of opportunity calculations in appendix D it can be seen that new product development (NPD) was the highest priority $(0.236)$ of technology managers in manufacturing environment opportunities for selection of a new manufacturing technology. In supply chain environment long term strategic relationship (0.424) and in general environment (0.682) were the highest priorities as shown in step6 of opportunity calculations in appendix D.

The risk aversion factor for each opportunity and threat was also calculated and documented as described in detail in step7 of appendix. For example, from step7 of opportunity calculations in appendix D it can be observed that managers assigned new product development (NPD) a risk aversion factor of (0.3), operations and support (0.7) and long term strategic relationship with suppliers (0.4). This means that technology managers will prefer a technology that facilitates new product 
development (NPD) and helps to form long term strategic relationship with their suppliers by helping to optimise daily operations.

Finally, pairwise comparison was conducted between three defined environments as shown in step8 of opportunity calculations in appendix D using AHP. It was interesting to note that managers preferred to give subsequently more importance to supply chain opportunities by giving a weight of (0.627) in comparison to manufacturing opportunities (0.28) and general environment (0.094). This showed that managers wanted to involve supply chain concerns more in their choice of selecting a new technology alternative. These calculation acted as input to the strategic assessment model (SAM) employed in the technology selection framework to determine the risk adjusted strategic value for different technology alternatives. The overall risk adjusted strategic value for each technology alternative calculated by this method is described in table 1 . The detailed results are presented in the appendix D.

Insert Table 1. Risk adjusted strategic value for technology alternatives

The detail results in appendix D show that if only opportunities in manufacturing environment were to be considered for technology selection then robot based technology alternative was the ideal technology (0.245) with server driven flexible technology (0.241) as the next best technology alternative. However, the introduction of the concept of threats and supply chain environment changes the overall technology selection results. The total opportunity value associated with robot based 
technology in manufacturing, supply chain and general environment is (0.62), whereas the total threat value associated with robot based technology in the three environment is (-0.284). Similarly, in case of server driven flexible technology the total opportunity value in three environments is $(0.668)$ and the total threat in three environments is $(-0.277)$. Lastly the existing technology offered opportunity value of (0.193) and threat value of (-0.186). The overall selection of technology was based on algebraic sum of opportunity and threat values offered by three technology alternatives as shown in table 1 . From table 1 it is clear that server driven flexible technology is the best technology alternative for "Bag in Box" when the risk associated with each of the identified technology alternatives is considered in terms of opportunities and threats in manufacturing, supply chain and general environment.

The results presented in table 1 are significant in the context that the company was planning to re-evaluate and redesign its supply chain by rationalising the supplier base and appropriately choosing the desired planning and coordination mechanism among its suppliers. The first step in this respect was to have the willingness in the company itself to include the intra-organisational benefits and concerns in their key decision making areas (technology). The reorganisation of the supply chain requires huge resource commitment in terms of finance and time. The company wanted to be ensured it had the right mechanisms to be aware of its supply chain needs as they realised the increasing pressure from their market competitors and their growing reliance on the supply chain for procurement and distribution activities. The company managers understood that investing in wrong manufacturing technology which only 
supports their own manufacturing activities and does not provide support to their supply chain will eventually cost them to lose their customers resulting in financial loss. Therefore, the technology selection framework presented in this paper facilitated the company managers to visualise the modern business reality that the economic survival of a company is linked with its supply chain as they say "supply chain competes not companies".

\section{Research Limitations}

The most basic aspect that was highlighted during the course of this research was to have the same understanding of different supply chain performance measures by all the people involved in the supply chain evaluation process. Similarly, it was very important to have the common understanding of the brainstormed opportunities and threats in the three different decision making environments. Therefore, in the detailed case study (Farooq and O'Brien, 2010) it was decided to have individual as well as group sessions with supply chain and technology managers so that everyone agreed on the same definitions. The concept of considering supply chain factors while selecting technology was new to the technology managers and therefore they were hesitant at the start with the evaluation process. It was noted that the SAM model used for risk calculations was sensitive to high threats value: meaning if the technology managers associated high threats values to a technology alternative compared to its opportunity value there is a fundamental mistake in considering that technology alternative in the first place. Clearly when a technology alternative offers 
more threats then opportunities it is no more a realistic alternative and thus should not be included in the technology selection process. During the implementation of the technology selection process it was noted that the technology managers found it difficult at first to understand the process of allocation of risk aversion factors to different opportunities and threats associated with each technology alternative. The risk aversion calculations required the process to be explained a number of times. This gave an indication to be clearer about risk aversion calculations in the future research.

\section{Future Research}

The research presented in this paper can be improved and facilitated by actively researching in the subject areas indicated below:

\subsection{Development of a prototype tool}

The systematic evaluation of the technology selection framework in different industrial sectors should be a subject of future research. The validation of the technology selection framework in the industry can lead to a prototype tool development for technology selection process. The development of a software tool could greatly reduce the data needed to implement the technology selection framework. The tool should be developed with an idea of providing the necessary information that is mandatory for the decision maker for making the relevant strategic decisions. The availability of requisite information at a single source will able the time required to gather the necessary information for decision making to be reduced 
and will also be helpful in distributing standard unambiguous information to the decision makers throughout the organisation. Furthermore, the prototype tool can be a step towards the commercialisation of the technology selection framework.

\subsection{Improvement in risk calculation techniques}

The inclusion of risk calculations in the technology selection process is relatively new. The risk calculation methods used in the technology selection framework needs to be further investigated. The risk calculation techniques available in the literature need to be translated into industrial terms so that the technology managers can relate to these techniques and can provide an input that shows their real time risk concerns associated with different technology alternatives.

\subsection{Group decision support system (GDSS) facilitation}

The technology selection framework presented in this research depends on the active participation of the managers involved in the decision making process. In the absence of facilities for group decision making (GDSS) it was complex to move back and forth between the two function of manufacturing and supply chain. Moreover, as the researcher was acting as the messenger between the two sides there was a possibility of misinterpreting information. The collective participation of managers from two function would have further enhanced the decision making process. Therefore, it needs to be investigated how the availability of GDSS can further crystallise the technology selection decision making. This research could benefit greatly from the developments in GDSS by making use of a remote decision making facility. A remote 
decision making facility can be used to incorporate the supply chain members in the decision making process and this can lead towards the real integration of the supply chain where supply chain affairs are duly addressed by supply chain members in the strategic technology selection process.

\section{Conclusion}

In literature there are several traditional engineering economic analysis methods that are used for justifying new technology investments, for example net present value (NPV), internal rate of return and methods including payback period. These techniques primarily include the tangible financial costs and benefits. However, investment in a new technology is often hard to justify by just using the measurable cost and benefit data alone and investing in a new technology often result in uncertain future benefits that are very hard to estimate using a conventional financial analysis (Ordoobadi, 2009). The research presented in this paper has approached the subject of manufacturing technology selection from a broader perspective of supply chain. The motivation behind this research was the ever increasing emergence of global supply chains and a lack of literature to guide manufacturing technology selection in their presence. It is anticipated that application of this framework will help to highlight some tacit issues regarding the effects on the technology selection processes of such matters as dominance of the technologically advanced and better resourced supply member in a supply chain, strategic technology alliances to become an integral part of a successful supply chain and the effect of technology selection processes on a firm's 
global business strategies. The implementation of the technology selection framework in the industry helped in providing insight into the working of the proposed framework and the practical applicability of the framework improved the methods of data collection for the detailed case study as the success of the technology selection framework depended upon the human input of the supply chain and technology managers involved in the process. Therefore, it was necessary to maintain the interest of all involved in the technology selection process by actively engaging the members by educating them about the technology selection framework and being educated by them about their manufacturing and supply chain practices.

\section{Appendix A}

Interview for Development of Technology Selection Framework

Product Profile:

1. How important is the selection of the right kind of manufacturing technology for this product?
a. Very Important
b. Important
$\square$ c. Indifferent
d. Less Important
e. Not Important

2. Is your manufacturing technology selection influenced by the technology state of your supplier/distributor in your supply chain?
a. Yes
b. No
c. Other

3. How important is it for you to select your manufacturing technology keeping in view the technology status of your supplier/distributor (supply chain)?
a. Very Important
b. Important
$\square$ c. Indifferent
d. Less Important
e. Not Important 
4. How important is it to evaluate the current supply chain performance of the product (based on supply chain performance measures like cost, quality, lead time etc) compared to its market competitors before selecting a particular manufacturing technology?
a. Very Important
b. Important
c. Indifferent
d. Less Important
e. Not Important

5. Evaluation of current supply chain performance for the purpose of manufacturing technology selection requires?
a. Selection of Participants
b. Understanding of the purpose of the process
c. Understanding of business objective of the company
d. Other

6. Evaluation of current supply chain performance for the purpose of manufacturing technology selection provides?
a. Identification of strengths \& weaknesses
b. Relative comparisons with market competitors
c. Re-evaluation of business strategy
d. Other

7. How important is it to determine the critical supply chain performance factors/ market competition factors (like cost, quality, lead time etc) of a business before selecting a particular manufacturing technology perspective?
a. Very Important
b. Important
c. Indifferent
d. Less Important
e. Not Important

8. Determination of critical supply chain factors/market competition factors for the selection of manufacturing technology requires?

a. Definition of important factors for market competition

b. Evaluation of supply chain members (their business priorities)

c. Collaboration with supply chain members (working towards same business objective)

d. Other 
9. Determination of critical supply chain/market competition factors for the selection of manufacturing technology provides?
a. Identification of core competency
b. Set of factors for market competition
c. Re-defined Business Strategy
d. Other

10. How important is it to establish a time horizon /planning range (short time, medium time, long time) to necessitate the implementation of supply chain/market competition factors while considering selection of a manufacturing technology?
a. Very Important
b. Important
c. Indifferent
d. Less Important
e. Not Important

11. Determination of time horizon for implementation of supply chain/market competition factors requires?
a. Nature of market/business
b. Support from the supply network
c. Other

12. Determination of time horizon for implementation of supply chain/market competition factors provides?
a. Future vision of the business (supply chain)
b. Requirement of means to execute the planned action
c. Defining resource allocation
d. Other

13. How important is to identify the potential manufacturing technologies to fulfil the criteria of supply chain/market competition factors (like cost, quality, lead time, etc) within a specific time horizon before selection of a particular technology?
a. Very Important
b. Important
c. Indifferent
d. Less Important
e. Not Important

14. Identification of a particular manufacturing technology to fulfil the criteria of supply chain/market competition requires? 
a. Time Horizon

b. Critical Supply Chain Factors

c. Technology status of supply chain members

d. Other

15. Identification of a particular manufacturing technology to fulfil the criteria of supply chain/market competition provides?
a. Identification of latest and advanced technologies
b. List of possible technologies to achieve the goal
c. Detailed characteristics of each alternative
d. Other

16. How important is the detailed assessment of identified manufacturing technologies in order to select the right manufacturing technology?
a. Very Important
b. Important
c. Indifferent
d. Less Important
e. Not Important

17. Detailed assessment of manufacturing technologies for the purpose of technology selection requires?
a. Expert analysis
b. Technology associated Opportunities
c. Technology associated Threats
d. Other

18. Detailed assessment of manufacturing technologies for the purpose of technology selection provides?
a. Detailed analysis under different scenarios
b. Defined set of technology to achieve the goal
c. 'What If' analysis in case business objective changes
d. Other

19. How important is the assessment of risk associated with a technology alternative while selecting a manufacturing technology? 

a. Very Important
b. Important
c. Indifferent
d. Less Important
e. Not Important

\section{Appendix B}

\section{Supply Chain and Market Evaluation Questionnaire}

Product Profile:

1. Please identify the supply chain performance objectives that are important to the success of the product?
a. Cost $\square$
b. Quality
c. Lead Time
d. New Product Development
e. Flexibility
f. Other

2. For each of the above mentioned objectives please identify how important is this objective to your product supply chain?

\begin{tabular}{|l|l|l|l|l|l|}
\cline { 2 - 6 } \multicolumn{1}{c|}{} & $\begin{array}{c}\text { Very } \\
\text { Important }\end{array}$ & Important & Indifferent & $\begin{array}{c}\text { Less } \\
\text { Important }\end{array}$ & $\begin{array}{c}\text { Not } \\
\text { Important }\end{array}$ \\
\hline Cost & & & & & \\
\hline Quality & & & & & \\
\hline Lead Time & & & & & \\
\hline New Product & & & & & \\
\hline Flexibility & & & & & \\
\hline Others.... & & & & & \\
& & & & & \\
\hline
\end{tabular}

http://mc.manuscriptcentral.com/tprs Email: ijpr@lboro.ac.uk 
3. What is your supplier's performance (supply chain) at delivering the above objectives to for the given product?

\begin{tabular}{|l|l|l|l|l|l|}
\cline { 2 - 6 } \multicolumn{1}{c|}{} & Excellent & Very Good & Good & Satisfactory & Unsatisfactory \\
\hline Cost & & & & & \\
\hline Quality & & & & & \\
\hline Lead Time & & & & & \\
\hline $\begin{array}{l}\text { New Product } \\
\text { Development }\end{array}$ & & & & & \\
\hline Flexibility & & & & & \\
\hline Others.... & & & & & \\
\end{tabular}


4. For this product or service does each performance objective meet the following?

\begin{tabular}{|c|c|c|c|c|c|c|c|c|c|}
\hline & $\begin{array}{l}\text { Provide a } \\
\text { crucial } \\
\text { advantage } \\
\text { with } \\
\text { customers }\end{array}$ & $\begin{array}{l}\text { Provide an } \\
\text { important } \\
\text { advantage } \\
\text { with most } \\
\text { customers }\end{array}$ & $\begin{array}{l}\text { Provide a } \\
\text { useful } \\
\text { advantage } \\
\text { with most } \\
\text { customers }\end{array}$ & $\begin{array}{l}\text { Need to be } \\
\text { at least up } \\
\text { to good } \\
\text { industry } \\
\text { standard }\end{array}$ & $\begin{array}{l}\text { Need to be } \\
\text { around } \\
\text { median } \\
\text { industry } \\
\text { standard }\end{array}$ & $\begin{array}{l}\text { Need to be } \\
\text { within close } \\
\text { range of the } \\
\text { rest of the } \\
\text { industry }\end{array}$ & $\begin{array}{l}\text { Do not usually come } \\
\text { into customers } \\
\text { consideration but } \\
\text { could become more } \\
\text { important in future }\end{array}$ & $\begin{array}{l}\text { Very rarely } \\
\text { come into } \\
\text { customers } \\
\text { considerations }\end{array}$ & $\begin{array}{l}\text { Never come } \\
\text { into } \\
\text { consideration } \\
\text { by customers }\end{array}$ \\
\hline Cost & & & 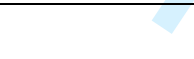 & & & & & & \\
\hline Quality & & & & & 3 & & & & \\
\hline Lead Time & & & & & & & & & \\
\hline $\begin{array}{l}\text { New Product } \\
\text { Development }\end{array}$ & & & & & & & & & \\
\hline Flexibility & & & & & & & & & \\
\hline Others..... & & & & & & & & & \\
\hline 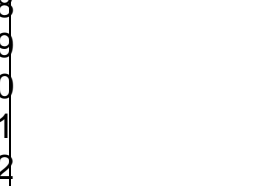 & & & & & & & & & \\
\hline
\end{tabular}


5. In this market sector or for this product group how is your achieved performance in each of the performance objectives?

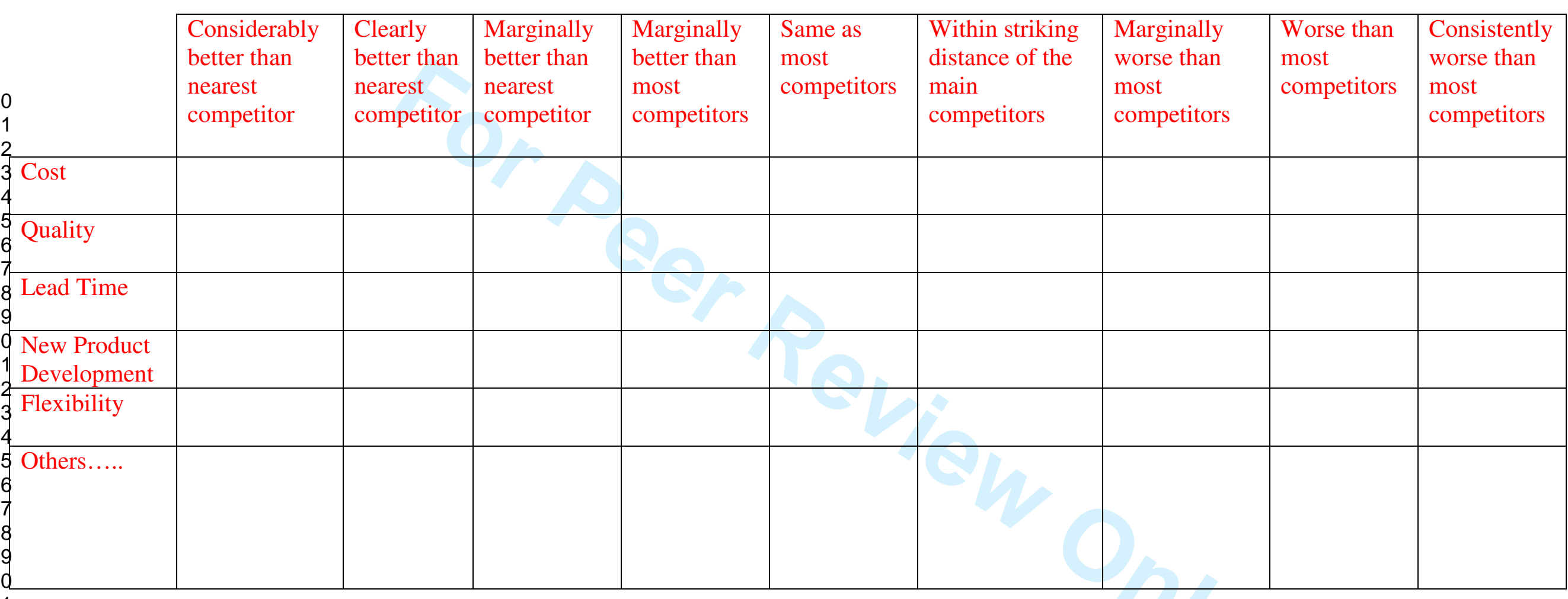




\section{Technology Probability Table}

Considering "Bag in Box" please identify the opportunities and threats presented by each technology alternative in manufacturing, supply chain and general environment and also highlight the probability of occurrence of the identified opportunity or threat if a particular technology is selected. Use a scale from $0-100 \%$ in the increasing order to represent the probability of occurrence where 0 represents no probability and 100 shows full probability (certainty) of occurrence.

\begin{tabular}{|l|l|l|l|l|}
\hline $\begin{array}{c}\text { Manufacturing } \\
\text { Environment } \\
\text { Opportunity }\end{array}$ & $\begin{array}{c}\text { Robot Based } \\
\text { Technology (Highly } \\
\text { Flexible/ Automated) }\end{array}$ & $\begin{array}{c}\text { Server Driven } \\
\text { Flexible Technology } \\
\text { (Moderately Flexible) }\end{array}$ & $\begin{array}{c}\text { Existing Technology } \\
\text { (Low Flexibility) }\end{array}$ & $\begin{array}{c}\text { Certainty Equivalence } \\
\text { C.E }\end{array}$ \\
\hline $\begin{array}{l}\text { Reduction of } \\
\text { Staff }\end{array}$ & & & & \\
\hline $\begin{array}{l}\text { Increased } \\
\text { Productivity }\end{array}$ & & & & \\
\hline Improved Quality & & & & \\
\hline $\begin{array}{l}\text { New Product } \\
\text { Development }\end{array}$ & & & & \\
\hline $\begin{array}{l}\text { Competitive Edge } \\
\text { over Competitors }\end{array}$ & & & & \\
\hline $\begin{array}{l}\text { Increase in } \\
\text { Market Share }\end{array}$ & & & & \\
\hline $\begin{array}{l}\text { Supply Chain } \\
\text { Environment } \\
\text { Opportunity }\end{array}$ & & & & \\
\hline $\begin{array}{l}\text { Long Term } \\
\text { Strategic } \\
\text { Relationship }\end{array}$ & & & & \\
\hline $\begin{array}{l}\text { Sharing of Risk } \\
\text { and Rewards }\end{array}$ & & & & \\
\hline $\begin{array}{l}\text { Joint Continuous } \\
\text { Improvement }\end{array}$ & & & & \\
\hline $\begin{array}{l}\text { Product Volume } \\
\text { Flexibility }\end{array}$ & & & & \\
\hline $\begin{array}{l}\text { General } \\
\text { Environment } \\
\text { Opportunity }\end{array}$ & & & & \\
\hline $\begin{array}{l}\text { Benefits from } \\
\text { Govt Regulations }\end{array}$ & & & & \\
\hline $\begin{array}{l}\text { National } \\
\text { International } \\
\text { Prominence }\end{array}$ & & & & \\
\hline $\begin{array}{l}\text { Operation and } \\
\text { Support }\end{array}$ & & & & \\
\hline $\begin{array}{l}\text { Manufacturing } \\
\text { Environment }\end{array}$ & & & & \\
\hline
\end{tabular}




\begin{tabular}{|l|l|l|l|l|}
\hline Threat & & & & \\
\hline Staff Resistance & & & & \\
to Change & & & & \\
\hline Training & & & & \\
\hline Expenses & & & & \\
\hline System & & & \\
Integration & & & & \\
\hline Technology & & & & \\
Maturity & & & & \\
\hline Industrial Action & & & & \\
\hline Supply Chain & & & & \\
Environment & & & & \\
Threat & & & & \\
\hline In Adequate & & & & \\
Technology & & & & \\
\hline Technical Ability & & & & \\
\hline Knowledge of & & & & \\
Business & & & & \\
Opportunities & & & & \\
\hline Commitment to & & & & \\
Innovation & & & & \\
\hline Communication & & & & \\
Gap & & & & \\
\hline General & & & \\
Environment & & & & \\
Threat & & & & \\
\hline Lean Economy & & & & \\
\hline Life Cycle & & & & \\
\hline Return on & & & & \\
Investment & & & & \\
\hline
\end{tabular}

\section{Appendix D}

1. Strategic assessment model (SAM) calculations

The following steps describe a solvable approach in which the calculations are carried out in the Microsoft Excel for strategic technology alternative using SAM.

\section{a. Opportunity calculations:}

Step 1 and Step 2: The first two steps involved calculations of constant ( $K$ )

$$
K=1 / \operatorname{lnq}
$$

$q=$ Total Number of Alternatives 
Step 3: In step 3 entropy measure of all the defined opportunities in three defined decision making environments manufacturing, supply chain and general environment is determined.

$$
e\left(p_{u i j}\right)=-K \sum_{m=1}^{q} \frac{p_{u i j}^{m}}{P_{i j}} \ln \frac{p_{u i j}^{m}}{P_{i j}}
$$

In equation (1)

$e\left(p_{u i j}\right)=$ Entropy Measure of jth Opportunity Factor in the ith Environment $\mathrm{q}=$ Total Number of Alternatives

$K=1 / \operatorname{lnq}$

$p_{u i j}^{m}=$ The mth Probability of Occurrence of the jth Opportunity Factor in the ith Environment $P_{i j}=$ Sum of Probability of Occurrences of the jth Opportunity Factor in the ith Environment

Step 4: In step 4 the Total Entropy is calculated.

$$
E=\sum_{j=1}^{N u i} e\left(p_{u i j}\right)
$$

In equation (2)

$E \quad=$ Total Entropy

$N_{u i}=$ Number of Opportunity Factors in the ith Environment

$e\left(p_{u i j}\right)=$ Entropy Measure of the jth Opportunity Factor in the ith Environment

Step5: In step 5 intrinsic weight of all the opportunities in all three decision making environments is determined.

$$
F_{u i j}=\frac{1}{N_{u i}-E}\left[1-e\left(p_{u i j}\right)\right]
$$

In equation (3)

$F_{u i j}=$ Intrinsic Weight for the jth opportunity Factor in the ith Environment

$N_{u i}=$ Number of Opportunity Factors in the ith Environment

$E=$ Total Entropy

Step 6: In step 6 initial weight associated with each opportunity factor in all three decision making environment is determined using Analytical Hierarchy Process (AHP) and then overall importance weight of an opportunity is determined. 


$$
\hat{F}_{u i j}=\frac{F_{u i j .} \mathcal{W}_{u i j}}{\sum_{j=1}^{N u i} F_{u i j} . W_{u j}}
$$

In equation (4)

$$
\begin{aligned}
& \hat{F}_{u i j}=\text { Overall Importance Weight for the jth opportunity Factor in the ith Environment } \\
& F_{u i j}=\text { Intrinsic Weight for the jth opportunity Factor in the ith Environment } \\
& w_{u i j}=\text { Initial Weight Associated for the jth opportunity Factor in the ith Environment }
\end{aligned}
$$

Step 7: In step 7 risk aversion factors are calculated for each opportunity equating utility of certainty equivalence (C.E) and utility of an exponential function.

$$
\begin{aligned}
& \text { Utility of Certainty Equivalence }=u(\mathrm{C} . \mathrm{E})=0.5 u(1)+0.5 u(0) \\
& \text { Utility of an Exponential Function }=u=1 / r\left(1-e^{+p}\right)
\end{aligned}
$$

Equating equation (5) and (6) putting $p=\mathrm{C} . \mathrm{E}$

$$
\begin{aligned}
& 1 / r\left(1-e^{+p}\right)=0.5\left[1 / r\left(1-e^{+p}\right)\right]+0 \\
& e^{+p}-0.5 e^{-r}=0.5
\end{aligned}
$$

The technology managers were asked the possibility of occurrence and possibility of non occurrence of an opportunity and threat as shown in equation (5). Where 1 represents occurrence and 0 represents non occurrence of an opportunity or threats. So the expected value of lottery in equation (5) is 0.50 and the technology managers were asked to provide a C.E value between 0 and 0.50 where 0 represented complete risk aversion and 0.50 represented complete risk neutrality. Using equation (7) the corresponding value of risk aversion factor was then determined.

Step8: In step 8 the risk adjusted opportunity value is calculated.

$$
U^{m}=\sum_{i=1}^{3} W_{u i}\left[\sum_{j=1}^{N u i} \hat{F} u\left[i j\left\{\frac{-1}{r_{u i j}} \ln \left(1-p_{u i j}^{m}+p_{u i j}^{m} e^{-r_{u j}}\right)\right\}\right]\right.
$$

In equation (8) 
$U^{m}=$ Total Weighted Risk Adjusted Opportunity Value of the mth Alternative

$W_{u i}=$ The ith Environment Weight for Opportunity

$N_{u i}=$ Number of Opportunity Factors in ith Environment

$\hat{F}_{u i j}=$ Overall Importance Weight for the jth Opportunity Factor in the ith Environment

$r_{u i j}=$ Risk Aversion Constant for jth Opportunity Factor in the ith Environment

$p_{u i j}^{m}=$ The mth Probability of Occurrence of jth Opportunity Factor in the ith Environment

b. Threat calculations:

The procedure for determination of threat calculations is exactly the same like opportunity calculations using the similar equations only replacing opportunity factor values with the threat value factors. The final risk adjusted threat value is calculated using the following equation:

$$
T^{m}=\sum_{t=1}^{3} W_{t i}\left[\sum_{j=1}^{N t i} \hat{F}_{t i j}\left\{\frac{-1}{r_{t i j}} \ln \left(1-p_{t i j}^{m}+p_{t i j}^{m} e^{r_{t j}}\right)\right\}\right]
$$

In equation (9)

$T^{m}=$ Total Weighted Risk Adjusted Threat Value of the mth Alternative

$W_{t i}=$ The ith Environment Weight for Threat

$N_{t i}=$ Number of Threat Factors in the ith Environment

$\hat{F}_{t i j}=$ Overall Importance Weight for the jth Threat Factor in the ith Environment

$r_{t i j}=$ Risk Aversion Constant for jth Threat Factor in the ith Environment

$p_{t i j}^{m}=$ The mth Probability of Occurrence of jth Threat Factor in the ith Environment

c. Overall risk adjusted strategic value:

The overall risk adjusted strategic value for technology alternative is calculated by using the following equation:

$$
V^{m}=U^{m}+T^{m}
$$

In equation (10)

$V^{m}=$ Total Weighted Risk Adjusted Strategic Value of the mth Alternative

$U^{m}=$ Total Weighted Risk Adjusted Opportunity Value of the mth Alternative

$T^{m}=$ Total Weighted Risk Adjusted Threat Value of the mth Alternative 
3. 'Bag in Box' detailed calculations

a. 'Bag in Box' calculations (Opportunities)

Insert Bag in Box calculations (Opportunities) Table

b. 'Bag in Box' calculations (Threats)

\author{
Insert Bag in Box calculations (Threats) Table
}

\title{
References
}

Amin, G.R., Toloo, M. and Sohrabi, B., 2006. An improved MCDM DEA model for technology selection. International Journal of Production Research, 44(13), 2681- 2686.

Chatterji, D., 1996. Accessing external sources of technology. Research -Technology Management, 48-56.

Dyer, J.H., 1996. Specialised supplier networks as a source of competitive advantage: Evidence from the auto industry. Strategic Management Journal, 17, 649-666.

Dyer, J.H. and Singh, H., 1998. The relational view: Cooperative strategy and source of interorganisational competitive advantage. Academy of Management Review, 23(4), 660-679.

Farooq, S., O'Brien, C., 2010. Risk calculations in the manufacturing technology selection process. Journal of Manufacturing Technology Management, 21(1), 28-49.

Fine, C.H., 1999. Clock speed strategies for supply chain advantage. Supply Chain Management Review, Global Supplement, 4-7.

Fine, C.H., Hax, A.C., 1985. Manufacturing strategy: a methodology and an illustration. Interfaces 15(6), 28-46.

Gagnon, R.J., Haldar, S., 1997. Assessing advanced engineering technologies. International Journal of Technology Management 14, 439-469.

Gouvea da Costa, S.E., Platts, K.W., Fleury, A., 2006. Strategic selection of advanced manufacturing technologies based on the manufacturing vision. International Journal of Computer Applications in Technology, 27(1), 12-23.

Gregory, M.J., Probert, D.R., Cowell, D.R., 1996. Auditing technology management processes. International Journal of Technology Management, 12(3), 306-319.

Hayes, R.H., Wheelwright, S.C., 1984. Restoring Our Competitive Edge: Competing Through Manufacturing. John Wiley and Sons, New York.

Kengpol, A., O'Brien, C., 2001. The development of a decision tool for the selection of advanced technology to achieve rapid product development. International Journal of Production Economics 69, 177-191. 
Karsak, E.E. and Ahiska, S.S., 2005. Practical common weight multi-criteria decision making approach with an improved discriminating power for technology selection. International Journal of Production Research, 43, 1537-1554.

Karsak, E.E. and Ahiska, S.S., 2008. Improved common weight MCDM model for technology selection. International Journal of Production Research, 46(24), 6933-6944.

Khouja, M., 1995. The use of data envelopment analysis for technology selection. Computers and Industrial Engineering, 28(1), 123-132.

Kim, B., 2003. Managing the transition of technology life cycle. Technovation, 23, 372-381.

Kleindorfer, P.R., Partovi, F.Y., 1990. Integrating manufacturing strategy and technology choice. European Journal of Operational Research, 47, 214-224.

Lowe, A., Ridgway, K., Atkinson, H., 2000. QFD in new production technology evaluation, International Journal of Production Economics, 67, 103-112...

Mohanty, R.P., Deshmukh, S.G., 1998. Advanced manufacturing technology selection: A strategic model for learning and evaluation. International Journal of Production Economics, 55, 295-307.

Ordoobadi, S., 2009. Evaluation of advanced manufacturing technologies using taguchi's loss function. Journal of Manufacturing Technology Management 20(3), 367-384.

Poirier, C.C., 1999. Advanced Supply Chain Management: How to Build a Sustained Competitive Advantage. Berrett-Koehler Publishers, San Francisco.

Punniyamoorthy, M., Ragavan, P.V., 2003. A strategic decision model for the justification of technology selection. International Journal of Advanced Manufacturing Technology, 21, 7278.

Rosenzweig, E.D., Roth, A.V. and Dean, J.W., 2003. The influence of an integration strategy on competitive capabilities and business performance: an exploratory study of consumer products manufacturers. Journal of Operations Management, 21, 437-456.

Saaty, T.L., 1980. The Analytic Hierarchy Process. McGraw-Hill, New York.

Shehabuddeen, N., Probert, D., Phaal, R., 2006. From theory to practice: Challenges in operationalising a technology selection framework. Technovation, 26, 324-335.

Slack, N., 1994. The importance performance matrix as a determinant of improvement priority. International Journal of Operations and Production Management, 14(5), 59-75.

Swink, M., Narasimhan, R. and Wang, C., 2007. Managing beyond the factory walls: effects of four types of strategic integration on manufacturing plant performance. Journal of Operations Management, 25, 148-164. 
Tavana, M., Banerjee, S., 1995. Strategic assessment model (SAM) - A multiple criteria decision support system for evaluation of strategic alternatives. Decision Sciences, 26(1), 119-143.

Tavana, M., 2003. CROSS: A multi-criteria group decision making model for evaluating and prioritising advanced technology projects at NASA. Interfaces, 33(3), 40-56.

Torkkeli, M., Tuominen, M., 2002. The contribution of technology selection to core competencies. International Journal of Production Economics, 77, 271-284.

Yap, C.M., Souder, W.E., 1993. A filter system for technology evaluation and selection. Technovation, 13(7), 449-469. 
Step 1:

e(max)

1.099

(Opportunities)

Step 2:

$\mathrm{K}$

0.91

Step3:

Manufacturing Environment Factor

14 Reduction of Staff

15 ncreased Productivity

A $\quad$ B

$\begin{array}{ll}0.3 & 0.3\end{array}$

$\begin{array}{ll}0.9 & 0.8\end{array}$

$0.8 \quad 0.8$

$0.9 \quad 0.9$

16 New Product

17 Development

18ompetitive Edge over

$0.9 \quad 0.9$

19 Competitors

zocrease in Market Share

0.9

0.9

0.985

$e\left(p_{u 11}\right)$

0.864

$e\left(p_{u 15}\right)$

Supply Chain Environment

Factor A $\quad$ B

29 Sharing of Risks and

30 Rewards

3

32 Improvement

Product Volume

Flexibility

$\begin{array}{ll}0.6 & 0.7\end{array}$

B
0.7

$0.3 \quad 0.4$

$0.5 \quad 0.5$

$0.4 \quad 0.4$

0.902

$e\left(p_{u 22}\right)$

0.966

$e\left(p_{423}\right)$

0.936

General Environment

38

\section{9}

4

\section{4}

2

$$
e\left(p_{u 21}\right)
$$
A B

Factor

$\begin{array}{cc}\mathrm{A} & \mathrm{B} \\ 0.7 & 0.7\end{array}$

C

0.2

SUM

1.6

A

0.438

0.2

2

0.45

0.6

1.9

0.263

0.864

$e\left(p_{u 32}\right)$

0.895

$e\left(p_{u 31}\right)$

$0.5 \quad 0.8$

Step4:

48

49

50

51

52

53

54

55

56

Step5:

Manufacturing Environment

$\begin{array}{ll}F_{u 11} & 0.027 \\ F_{u 15} & 0.251\end{array}$

5.456

E(Supply Chain

Environment)

3.803

$\mathrm{E}(\mathrm{General}$

Environment)

$F_{u 13}$

0.073

$F_{u 14}$

0.251

$F_{u 16} \quad 0.251$

Supply Chain Environment

$F_{u 21}$

0.499

$F_{u 22}$

0.175

$F_{u 23}$

0.326

$F_{u 24}$

0.001 
General Environment
$F_{u 31}$
0.406

$F_{u 32}$

0.527

$F_{u 33}$

0.067

8

9

Step6:

$W_{u 11}$

0.037

$w_{u 12}$

$\boldsymbol{W}_{u 13}$

Wu14

$W_{u 15} \quad W_{u 16}$

Wu 21

$\mathcal{W}_{422}$

0.155

0.235

0.216

0.121

0.424

0.179

0.338

$W_{u 31}$

$\mathcal{W}_{432}$

$\mathcal{W}_{u 33}$

0.236

0.082

0.682

$\wedge$

$F_{u 11}$

$\hat{F}_{u 12}$

0.124

0.093

$\hat{F}_{u 13}$

$\hat{F}_{u 14}$

0.32

$F_{u 15}$

0.293

0.164

$F_{u 21}$

0.599

$F_{u 16}$

ค

$\hat{F}_{u 22}$

0.089

$\hat{F}_{u 23}$

0.312

$\hat{F}_{u 24}$

0.001

0.518

$\hat{F}_{u 32}$

0.234

0.248

\section{Step 7:}

Risk Aversion Factor

Manufacturing

Environment

Reduction of Staff $\quad 0.04$

27

28

29

30

31

32

3

34

35

36

37

38

39

40

41

42

43

44

45

46

47

48

49

50

51

52

53

54

55

56

New Product

Development

petitive Edge over

Competitors

crease in Market Share

Step8:

Manufacturing Environment Weight

0.28

0.2

0.4

0.3

0.2

0.1

Supply Chain

Environment

Long Term Strategic Relationship

Sharing of Risks and Rewards

Joint Continuous Improvement

Product Volume Flexibility

0.3

0.06

Environment
$0.4 \quad$ Benefit from Govt. Regulations

0.3

0.2 National/International Prominence

0.1

Operations and Support

0.7
Supply Chain Environment Weight 0.627
General Environment Weight 0.094

Robot based Technology wrt Manufacturing Environment

$$
\text { U } \quad 0.245
$$

Robot based Technology wrt Supply Chain Environment

$$
\text { U } \quad 0.313
$$

Robot based Technology wrt General Environment

$$
U
$$

$$
0.062
$$

Risk Adjusted Opportunity Value for Robot based Technology ( $U^{1}$ )

Server Driven Flexible Technology wrt Manufacturing Environment

$$
U \quad 0.241
$$

Server Driven Flexible Technology wrt Supply Chain Environment

$$
U
$$


Server Driven Flexible Technology wrt General Environment $U$ 0.069

Risk Adjusted Opportunity Value for Server Driven Flexible Technology ( $U^{2}$ )

Existing Technology wrt Manufacturing Environment

$U \quad 0.059$

Existing Technology wrt Supply Chain Environment

$U$ 0.109

Existing Technology wrt General Environment U $\quad 0.025$

Risk Adjusted Opportunity Value for Existing Technology $\left(U^{3}\right)$

0.193 
Step 1:

$\mathrm{e}(\max )$

(Threats)

1.099

Step 2:

$\mathrm{K}$

0.91

Step3:

Manufacturing Environment

$\begin{array}{ccc}\text { Factor } & \mathrm{A} & \mathrm{B} \\ \text { Staff resistance to } & 0.3 & 0.2 \\ \text { Change } & & \\ \text { Training Expenses } & 0.5 & 0.4 \\ \text { Employee Layoff } & 0.4 & 0.4 \\ \text { System Integration } & 0.3 & 0 . \\ \text { Technology } & 0.3 & 0.2 \\ \text { Maturity } & & \\ \text { Industrial Action } & 0.1 & 0.1 \\ & & \\ e\left(p_{t 11}\right) & 0.921 & \\ e\left(p_{t 15}\right) & 0.982 & \end{array}$

Supply Chain Environment

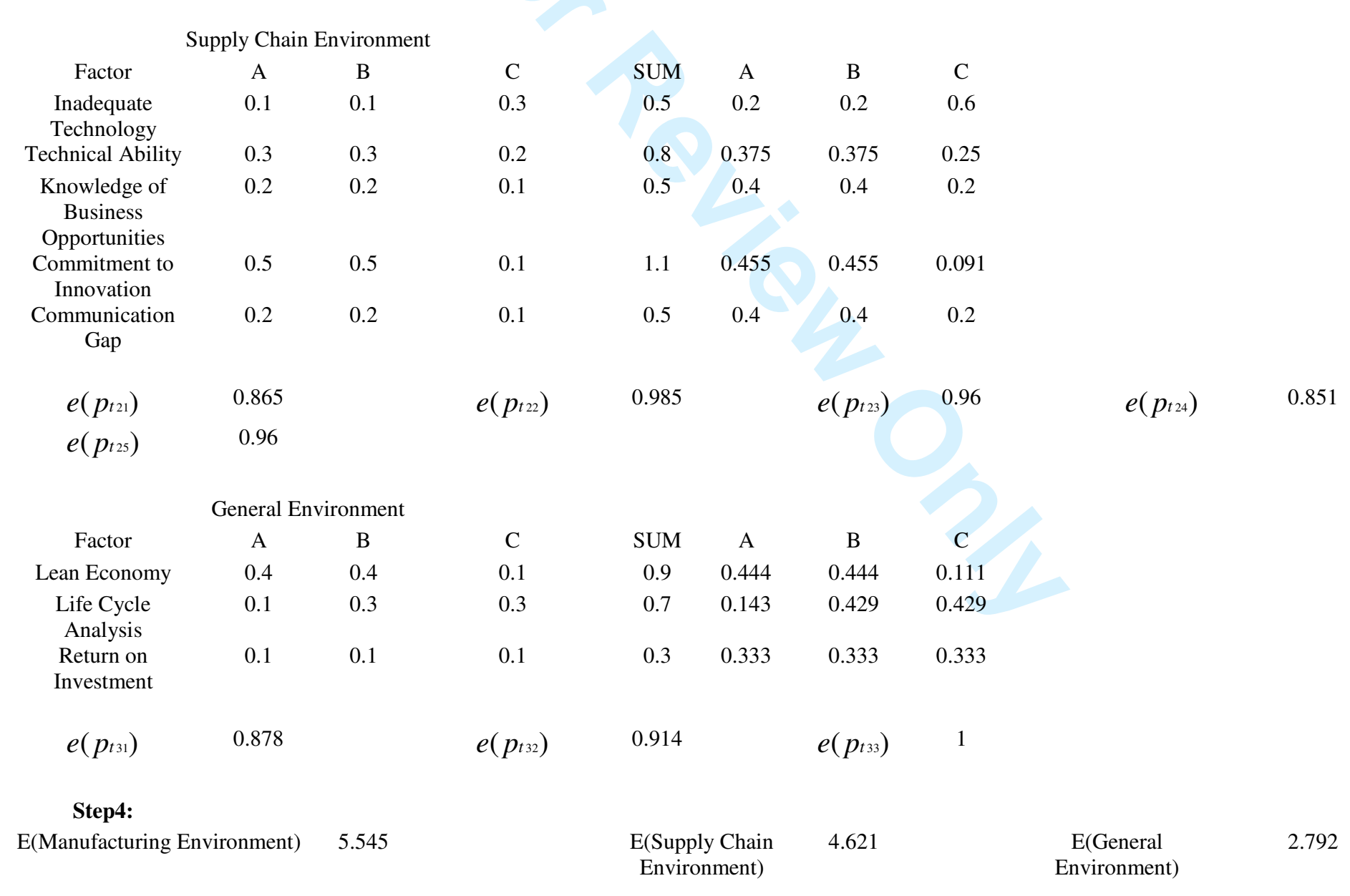

$\begin{array}{llll}\text { SUM A } & \text { B } & \text { C }\end{array}$

$\begin{array}{llll}0.6 & 0.5 & 0.333 & 0.167\end{array}$

$\begin{array}{llll}1 & 0.5 & 0.4 & 0.1\end{array}$

$\begin{array}{llll}0.9 & 0.444 & 0.444 & 0.111\end{array}$

$\begin{array}{llll}1.1 & 0.273 & 0.182 & 0.545\end{array}$

$\begin{array}{llll}0.7 & 0.429 & 0.286 & 0.286\end{array}$

$\begin{array}{llll}0.3 & 0.333 & 0.333 & 0.333\end{array}$

$0.859 \quad e\left(p_{t 13}\right) \quad 0.878$

$e\left(p_{t 14}\right)$

0.906 $e(p+14)$

(1) 


\section{Step5:}

Manufacturing Environment

$\begin{array}{ll}F_{t 11} & 0.175 \\ F_{t 15} & 0.039\end{array}$

Supply Chain Environment

$F_{t 21} \quad 0.357$

$F_{t 25} \quad 0.105$

General Environment

$\begin{array}{ll}F_{t 31} & 0.586\end{array}$

\section{Step6:}

$w_{t 11}$

0.297

$w_{t 22}$

0.252

$\hat{F}_{t 11}$

0.385

$\hat{F}_{t 15}$

0.121

$\hat{F}$

$F_{t 23}$

0.38

$\hat{F}_{t 32}$

0.788

\section{Step 7:}

Risk Aversion Factor

Manufacturing Environment

Staff resistance to Change

Training Expenses

Employee Layoff

System Integration

Technology Maturity

Industrial Action

Step8:

Manufacturing Environment Weight

0.28

0.3

0.09

0.1

0.04

0.4

0.05

$\begin{array}{ll}F_{t 12} & 0.311 \\ F_{t 10} & 0.001\end{array}$

$F_{t 16}$

$F_{t 13}$

0.268

$F_{t 14}$

0.208

$F_{t 22}$

0.039

$F_{t 23}$

0.105

$F_{t 24}$

0.394

\begin{abstract}
$F_{t 32}$
\end{abstract}
0.414

$F_{t 33}$

0.001 
2

3

4

5

6

7

8

9

10

11

12

13

14

15

16

17

18

19

20

21

22

23

24

25

26

27

28

29

30

31

32

33

34

35

36

37

38

39

40

41

42

43

44

45

46

47

48

49

50

51

52

53

54

55

56

57

58

59

60

$\begin{array}{ll}\mathrm{T} & -0.02\end{array}$

Risk Adjusted Threat Value for Robot based Technology ( $T^{1}$ )

Server Driven Flexible Technology wrt Manufacturing Environment

$\mathrm{T}$

$-0.09$

Server Driven Flexible Technology wrt Supply Chain Environment

$\mathrm{T}$

$-0.16$

Server Driven Flexible Technology wrt General Environment

$\mathrm{T}$ $-0.03$

Risk Adjusted Threat Value for Server Driven Flexible Technology ( $T^{2}$ )

Existing Technology wrt Manufacturing Environment

T $\quad-0.04$

Existing Technology wrt Supply Chain Environment

$\mathrm{T} \quad-0.12$

Existing Technology wrt General Environment

$\mathrm{T}$ $-0.03$

Risk Adjusted Threat Value for Existing Technology ( $\left.T^{3}\right)$

$-0.186$

http://mc.manuscriptcentral.com/tprs Email: ijpr@lboro.ac.uk 


\begin{tabular}{|c|c|}
\hline Risk Adjusted Strategic & Risk Adjusted Opportunity Value for Robot Based Technology \\
\hline Value for Robot Based & + \\
\hline \multirow[t]{2}{*}{ Technology } & Risk Adjusted Threat Value for Robot Based Technology \\
\hline & $0.62+(-0.284)=0.336$ \\
\hline Risk Adjusted Strategic & Risk Adjusted Opportunity Value for Server Driven Flexible \\
\hline Value Server Driven Flexible & Technology \\
\hline \multirow[t]{4}{*}{ Technology } & + \\
\hline & Risk Adjusted Threat Value for Server Driven Flexible \\
\hline & Technology \\
\hline & $0.668+(-0.277)=0.391$ \\
\hline Risk Adjusted Strategic & Risk Adjusted Opportunity Value for Existing Technology \\
\hline Value for Existing & + \\
\hline \multirow[t]{2}{*}{ Technology } & Risk Adjusted Opportunity Value for Existing Technology \\
\hline & $0.193+(-0.186)=0.007$ \\
\hline
\end{tabular}




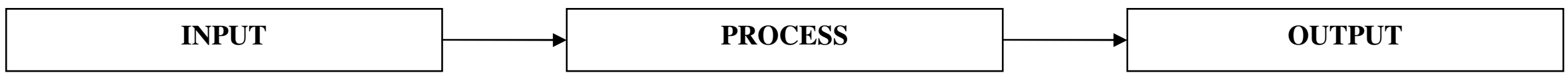

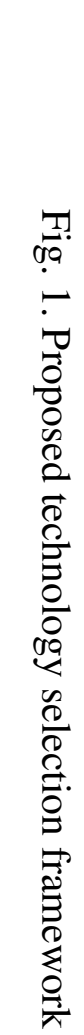

$\begin{aligned} & \text { Selection of Participants } \\ & \text { Purpose of the Process } \\ & \text { Business Objective of the Company }\end{aligned}$
Evaluation of Current Supply Chain
(Using Importance Performance Matrix)

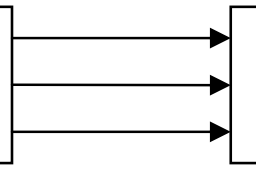

Identification of Strengths \& Weaknesses

Relative Comparison with Competitors

Re-evaluation of Business Strategy

Definition of Important Factors for Competition Purpose of the Process

Business Objective of the Company

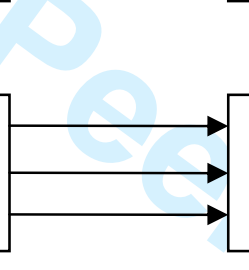

\section{Step 2}

Critical Supply Chain Factors on which

Company plans to Compete
Identification of Core Competency Set of Factors for Market Competition

Re-defined Business Strategy

Future Vision of the Business

Requirement of Means for Planned Action

Defining Resource Allocation

\section{Nature of Market/Business \\ Support from the Supply Network}

Planning Range/Time Horizon (Long Term, Medium Term, Short Term)
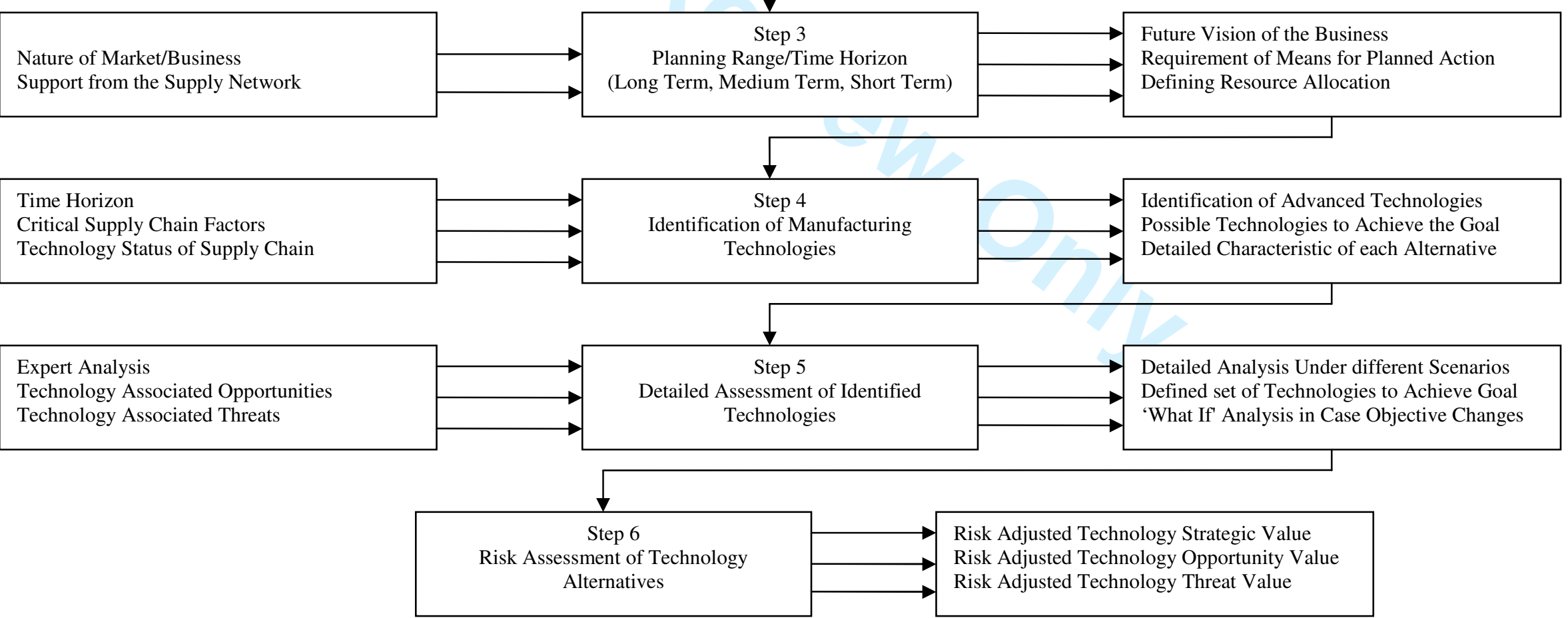

http://mc.manuscriptcentral.com/tprs Email: ijpr@lboro.ac.uk 


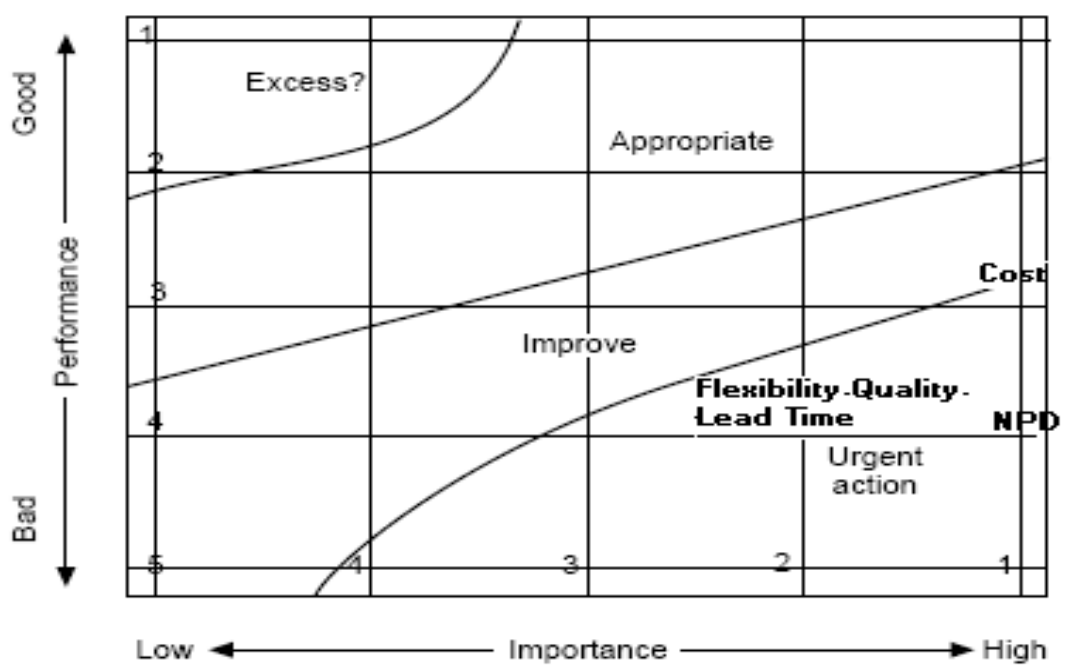

Fig. 2. Bag in Box importance performance for supply chain objectives 


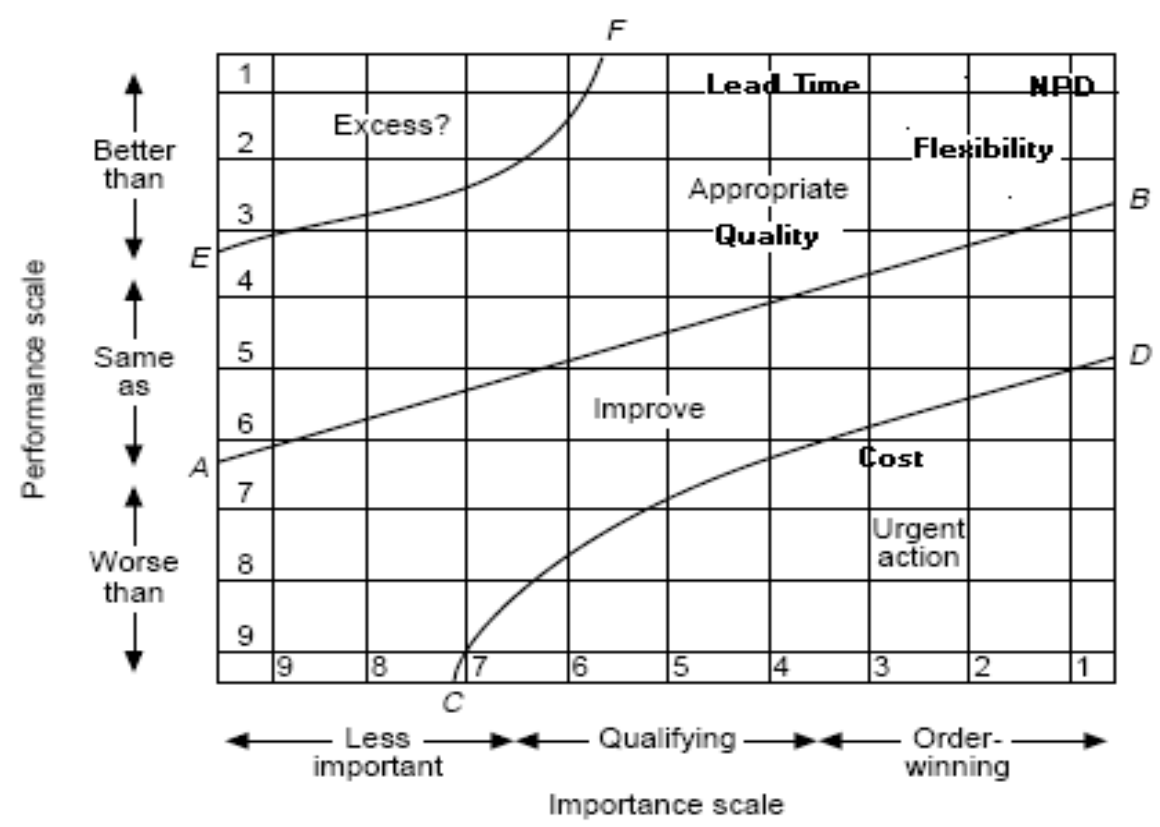

Fig. 3. Bag in Box market evaluation 


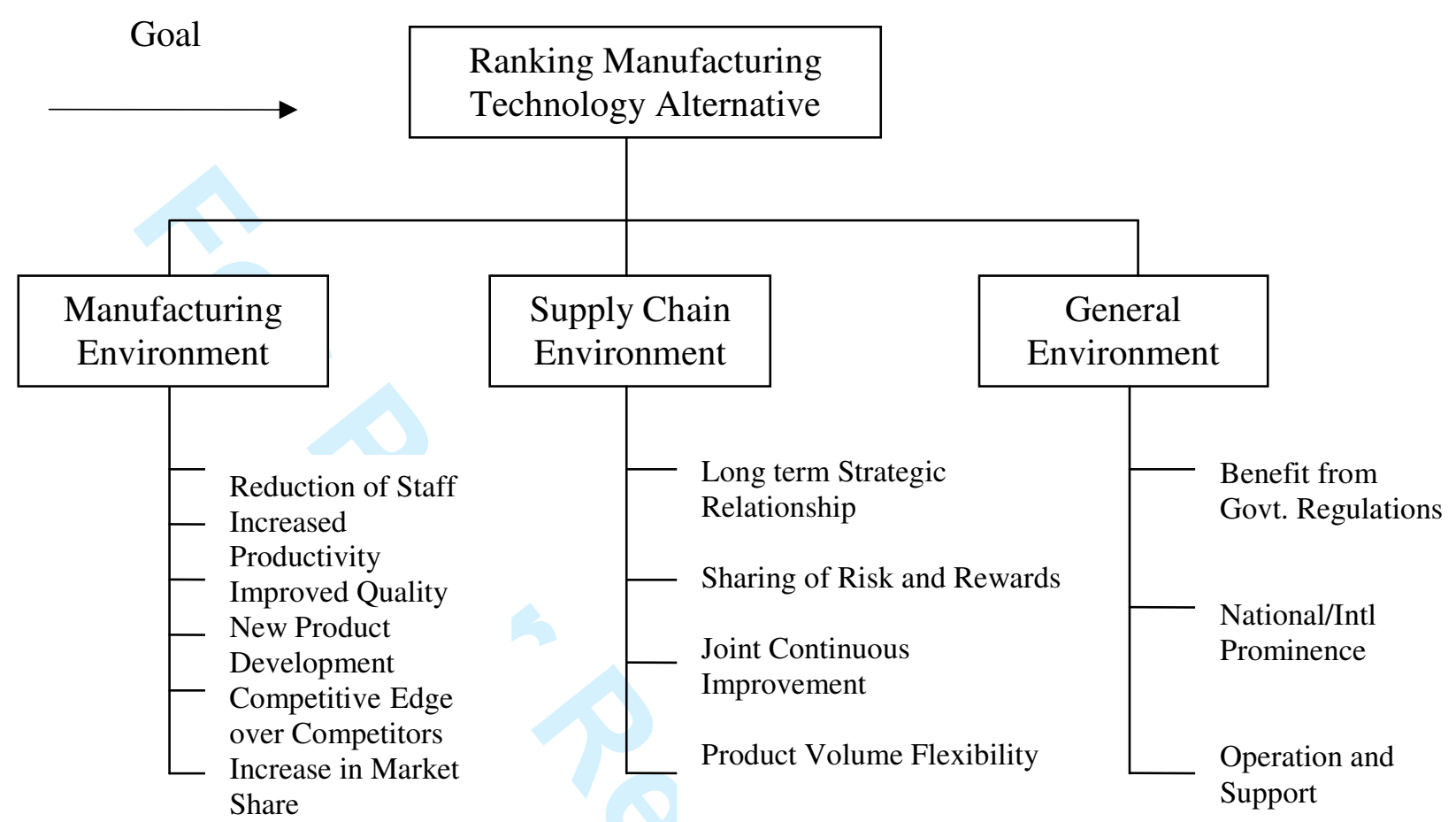

Fig. 4. AHP Bag in Box hierarchy (Opportunities) 
Fig. 5. AHP Bag in Box hierarchy (Threats) 